\title{
Bioconversion of Glutamic acid to $\gamma$-Aminobutyric acid (GABA) in Brown Rice Grains Induced by High Pressure Treatment
}

\author{
Toru SHIGEMATSU ${ }^{1, \dagger}$, Mina MURAKAMI ${ }^{1}$, Kanako NAKAJIMA ${ }^{1}$, Yoshiyuki UNO ${ }^{1}$, \\ Arata SAKANO ${ }^{1}$, Yuka NARAHARA ${ }^{1}$, Mayumi HAYASHI ${ }^{1}$, Shigeaki UENO ${ }^{2}$, \\ and Tomoyuki FUJII ${ }^{1,2}$
}

\author{
${ }^{1}$ Department of Food Science, Faculty of Applied Life Sciences, Niigata University of Pharmacy and Applied Life Sciences \\ (NUPALS), 265-1 Higashijima, Akiha-ku, Niigata, Niigata 956-8603, Japan \\ ${ }^{2}$ Graduate School of Agricultural Science, Tohoku University, \\ 1-1 Amamiya-machi, Tsutsumidori, Aoba-ku, Sendai 981-8555, Japan
}

\begin{abstract}
In this study, we supplied glutamic acid (Glu) into brown rice grains and allowed an enzymatic conversion from Glu to $\gamma$-aminobutyric acid (GABA) due to biosynthesis induced by high pressure (HP) treatment. The distribution of free amino acids in water-soaked brown rice grains during preservation after HP treatment at $200 \mathrm{MPa}$ for $10 \mathrm{~min}$ was analyzed. The free amino acid distribution of HP-treated samples, just after HP treatment, showed no apparent difference from that of untreated control without $\mathrm{HP}$ treatment. However, during 4 days preservation at $25^{\circ} \mathrm{C}$ after $\mathrm{HP}$ treatment, certain amino acids including GABA in the HP-treated samples increased with time and showed higher concentrations than those in untreated samples. To investigate the feasibility for use of HP-treated brown rice grains as a bioreactor producing GABA, Glu was supplied into brown rice grains during water soaking and applied for HP treatment. The GABA concentrations during preservation increased with the increase in the Glu concentrations in the soaking solutions. The initial GABA production rate was accelerated by HP treatment. These results provide feasibility for a novel use of HP technology to alter the metabolic pathways in a cellular biological material and to accumulate useful metabolites.
\end{abstract}

Key words: High pressure treatment, brown rice, $\gamma$-aminobutyric acid, bioconversion

\section{Introduction}

Rice (Oryza sativa) is an important crop especially in Asia. In Japan, water soaking has been traditionally practiced prior to rice cooking. During water soaking, the contents in rice grains could be changed by enzymes responsible for saccharification, proteolysis, and amino acid metabolisms. Saikusa et al. reported that soaking rice in water brought about remarkable changes in the component and content of free amino acid in the rice kernel; the most significant of these was an increase of $\gamma$-aminobutyric acid (GABA) content [1]. Based on this finding, an efficient and simple method via water soaking has been developed for production of GABA from rice germ [2,3]. In addition, glutamate decarboxylase (GAD) have been purified from lactic acid bacteria and were used to produce GABA-enriched food [4,5]. These efforts were to develop GABA-enriched functional foods,

(Received 9 Jun. 2010: accepted 12 Oct. 2010)

† Fax: +81-(0) 250-25-5145, E-mail: shige@nupals.ac.jp since GABA possesses physiological functions such as neurotransmission, induction of hypotension and diuretic and tranquilizer effects $[6,7]$.

High pressure (HP) processing is one of non-thermal techniques for microbial inactivation [8,9]. The pressurized products can be maintained almost fresh without the change in the flavor and nutrient component in comparison with the heated one, because HP does not alter covalent bonds of organic compounds in a foodstuff $[10,11]$. Avocado puree and tropical juices, which are well known in the world as examples of HP-processed foods, are the products that keep the quality fresh as possible. Thermal changes, such as off-flavor formation, texture softening, and destruction of colors and vitamins, occur on heating [12]. Therefore, the use of HP is of great advantage when we would like to keep a foodstuff fresh [13,14].

Moreover, the propagation of pressure in the medium is so rapid that HP treatment can easily give a uniform qualitative change. In contrast, heat treatment can lead spatial difference in temperature when it applied for a food material, because heat transfer takes considerable 
time compared with pressure.

The aim of research and development of HP technique in food industry is first non-thermal processing and sterilization $[10,15,16]$. Because low-molecular substances are not affected by HP treatment, foodstuffs have been able to be sterilized without the degeneration of medical ingredients. HP can inactivate the yeast cells which gives a bad effect to Kimchi without the inactivation of lactic acid bacteria, because lactic acid bacteria often resists HP more than the yeast [17]. However, the spore of Bacillus sp. cannot be inactivated by using only HP treatment [18]. So, the foodstuffs contaminated by the spore of Bacillus sp. are sterilized with the combined HP and thermal treatment $[19,20]$.

Recently, it has been proposed to use HP treatment on the usage of pre-processing food processing [21]. HP treatment above approximately $100 \mathrm{MPa}$ on a cellular biological material has led to the damage of the cell structure [22,23]. When internal cell structure and membrane structure are damaged, mass transfer inside is promoted [24]. Then, drying, absorption, extraction and so on are expected to accelerate. The rate of mass transfer depends on the damage of internal cell structure. For example, the drying rate of the agricultural product treated by HP was faster than that of the untreated product, slower than those treated by both freeze-thaw and heat, and close to that treated by chloroform vapor [25]. In addition, a novel biochemical reaction also progresses as a result of HP treatment below approximately 600 $\mathrm{MPa}$, where certain enzymes are still active. This HP-induced transformation, or "Hi-Pit [26]", which includes alternation of cellular structures and active enzymes, could change the component composition [26-28] and generate a novel compound in an agricultural product [29]. If HP treatment would give the suitable condition for certain biochemical reaction to an inside of agricultural product, the product could behave as a bioreactor.

In a previous paper, we reported that turnip (Brassica rapa) root treated by $\mathrm{HP}$ over $200 \mathrm{MPa}$ formed unique green-blue color during $7-\mathrm{d}$ storage at $4^{\circ} \mathrm{C}$. The mechanism of green-blue compound formation would be based on biochemical reactions [29]. We also reported that HP treatment at $200 \mathrm{MPa}$ resulted in high accumulation of free amino acids and GABA in water-soaked soybean (Glycine max) [28]. These findings could be explained by the Hi-Pit effect that HP enhanced the apparent activities of enzymes, GAD and/or proteases. HP treatment of water soaked rice grain could also modify the mass trans- fer inside and apparent activities of enzymes, resulting in HP-dependent change of distribution of free amino acids.

Kinefuchi et al. observed a high accumulation of GABA in brown rice during water soaking after HP treatment [30], possibly due to the Hi-Pit effect. The feasibility of a novel use of HP-treated brown rice grain as a bioreactor that converts glutamic acid (Glu) to GABA should be investigated. In this study, therefore, we applied water soaked brown rice grains for HP treatment and subsequent preservation. And effects of HP treatment on distribution dynamics of free amino acids during preservation period were analyzed. Moreover, we analyzed the effect of Glu concentration, which was supplied during water soaking, on the GABA production in the $\mathrm{HP}-$ treated and untreated brown rice grains.

\section{Materials and Methods}

\subsection{Sample preparation for HP treatment}

Brown rice (Oryza sativa L. ssp. Japonica, cv. Koshihikari) was harvested in 2006 and purchased at a local rice store on 20 Oct. 2006. A $20 \mathrm{~g}$ of brown rice grains was put in a polyethylene bag with $30 \mathrm{ml}$ of a soaking solution and sealed by a vacuum sealer FCB270 (Fuji Impulse, Toyonaka, Japan). A $0.2 \%(\mathrm{w} / \mathrm{v})$ sodium azide (Wako Pure Chemical Industries, Osaka, Japan) in distilled water containing sodium hydrogen $\mathrm{L}(+)$-glutamate monohydrate (Wako Pure Chemical Industries) at a concentration of $0,0.01,0.03,0.05,0.08,0.1$ or $0.5 \mathrm{~g} / \mathrm{ml}$ was used for the soaking solution. To prevent microbial growth, sodium azide was added to soaking solution at a final concentration of $0.2 \%(\mathrm{w} / \mathrm{v})$. The sealed grains suspended with a soaking solution were stored at $20^{\circ} \mathrm{C}$ for 22 hours to allow grains imbibe and swell.

\subsection{HP treatment and subsequent preservation}

Each pack of the soaked brown rice grains was put into the stainless-steel vessel $(60 \mathrm{~mm}$ in diameter, $180 \mathrm{~mm}$ in height) of the HP apparatus (WIP, Kobe Steel, Kobe, Japan), which was filled with distilled water as a hydraulic fluid. The piston with copper section pressurized the packed grains at $200 \mathrm{MPa}$ for $10 \mathrm{~min}$; the temperature was maintained at $25^{\circ} \mathrm{C}$ during compression. After $\mathrm{HP}$ treatment, the grains were washed by distilled water and swept with paper towel to remove water or Glu solution on surface. Approximately $4 \mathrm{~g}$ of the grains were separately packed in 5 polyethylene bags, sealed, and incubated for $0,1,2,3$ or $4 \mathrm{~d}$ at $25^{\circ} \mathrm{C}$. The brown rice grains, 
which was soaked in each soaking solution, without HP treatment was also prepared and used as untreated control. The untreated samples were applied for the incubation at $25^{\circ} \mathrm{C}$ together with the HP-treated samples.

\subsection{Free amino acid analysis}

After incubation at $25^{\circ} \mathrm{C}, 2 \mathrm{~g}$ of the grains were homogenized with $18 \mathrm{ml}$ of distilled water in a mortar. The extract was centrifuged at $6000 \times g$ for $3 \mathrm{~min}$. The supernatant was centrifuged again at $6000 \times g$ for $3 \mathrm{~min}$. The resulting supernatant was applied for free amino acid analysis. The free amino acids in the supernatant were extracted by a solid phase extraction and were derivatized by using EZ:faast amino acid analysis kit (Phenomenex, Torrance, CA, USA) followed by detection through gas chromatography [31]. A gas chromatograph equipped with a flame ionization detector (FID) (GC-14A, Shimadzu, Kyoto, Japan) was used with a capillary column Zebron Amino Acid GC Column $10 \mathrm{~m} \times 0.25$ $\mathrm{mm}$, supplied in the EZ:faast kit. The carrier gas was Helium at a flow rate of $1.7 \mathrm{ml} / \mathrm{min}$. The oven temperature program was as follows: initial temperature, $110^{\circ} \mathrm{C}$ for $1 \mathrm{~min}$; followed by a linear ramp at $24^{\circ} \mathrm{C} / \mathrm{min}$ up to $320^{\circ} \mathrm{C}$; and held at $320^{\circ} \mathrm{C}$ for $5 \mathrm{~min}$. The temperature of injection port and detector were kept at $250^{\circ} \mathrm{C}$ and $320^{\circ} \mathrm{C}$, respectively. Under these conditions, a $2 \mu 1$ of derivatized amino acid sample was injected in a split mode.

\section{Results and Discussion}

\subsection{Effect of HP treatment on distribution of} free amino acids in water-soaked brown rice

Brown rice grains, soaked in distilled water containing sodium azide, were applied for HP treatment at $200 \mathrm{MPa}$ for $10 \mathrm{~min}$. The free amino acid concentration in the brown rice sample just after HP treatment was measured. The brown rice samples, soaked in distilled water containing sodium azide, without HP treatment were used as untreated controls and applied for free amino acid analysis (Table 1, Fig. 1a). Glutamine (Gln) showed the highest concentration of $1.3 \mu \mathrm{mol} / \mathrm{g}$-rice. Isoleucine (Ile), phenylalanine (Phe), lysine (Lys) and tryptophan (Trp) were not detected. For non-protein amino acids, GABA and hydroxyproline (Hyp) were detected. Hydroxylysine (Hly) and cystine (C-C) were not detected. The GC-FID analysis in this study could not distinguish GABA and serine (Ser), because these two compounds showed an identical retention time; a single peak. Using a capillary electrophoresis coupled to electrospray ionization mass spectrometry (CE-ESI-MS/MS), GABA and Ser could be quantified separately. In our preliminary results obtained using a $\mathrm{P} / \mathrm{ACE}$ system MDQ (Beckman Coulter, Brea, CA, USA) with 3200QTRAP (AB Sciex, Foster City, CA, USA), the concentrations of GABA and Ser were 0.61 and $0.06 \mu \mathrm{mol} / \mathrm{g}$ in the HP-treated samples and in 0.51 and $0.05 \mu \mathrm{mol} / \mathrm{g}$ in the untreated control, respectively. The major component of this peak
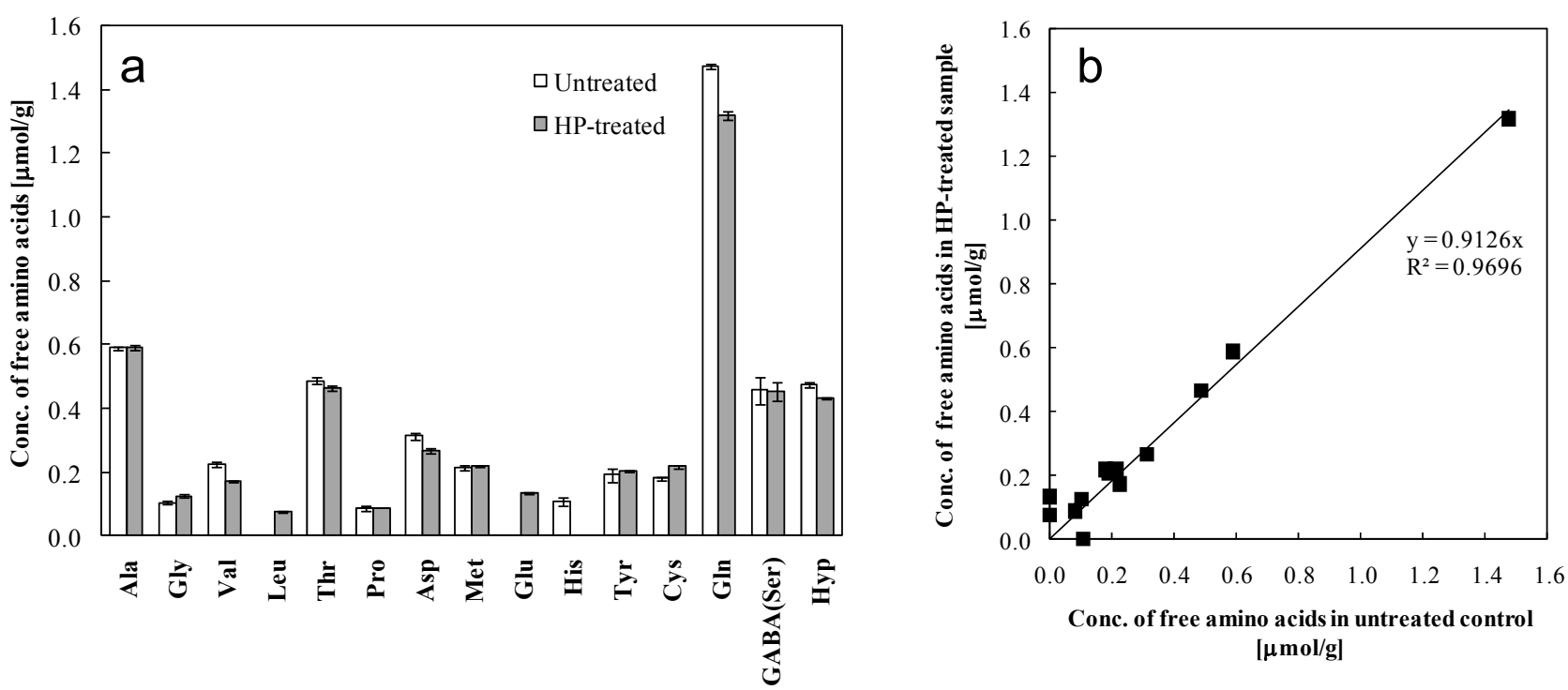

Fig. 1 Free amino acid concentration in HP-treated and untreated water-soaked samples just after HP treatment ( 0 d). All values were average of three measurements. Panel a; HP-treated (closed bars) and untreated (open bars) samples were shown with error bars representing the standard deviations. Panel b; for each amino acid, a point having the concentrations in untreated (horizontal axis) and HP-treated (vertical axis) samples was displayed in a scatter plot. A fitted curve was shown with the formula. 
Table 1 Free amino acid concentration of HP-treated and untreated water-soaked brown rice grains during preservation for $0 \mathrm{~d}$ to $4 \mathrm{~d}$.

\begin{tabular}{|c|c|c|c|c|c|c|c|c|}
\hline & \multicolumn{2}{|c|}{$0 \mathrm{~d}$} & \multicolumn{2}{|c|}{$1 \mathrm{~d}$} & \multicolumn{2}{|c|}{$2 \mathrm{~d}$} & \multicolumn{2}{|c|}{$4 \mathrm{~d}$} \\
\hline & Untreated & HP-treated & Untreated & HP-treated & Untreated & HP-treated & Untreated & HP-treated \\
\hline Ala & $0.589 \pm 0.006$ & $0.588 \pm 0.008$ & $0.550 \pm 0.001$ & $0.895 \pm 0.007$ & $0.624 \pm 0.008$ & $0.966 \pm 0.008$ & $0.777 \pm 0.010$ & $1.265 \pm 0.008$ \\
\hline Gly & $0.103 \pm 0.005$ & $0.124 \pm 0.005$ & $0.219 \pm 0.007$ & $0.499 \pm 0.005$ & $0.354 \pm 0.007$ & $0.582 \pm 0.011$ & $0.575 \pm 0.006$ & $0.829 \pm 0.008$ \\
\hline Val & $0.224 \pm 0.006$ & $0.172 \pm 0.002$ & $0.149 \pm 0.004$ & $0.374 \pm 0.002$ & $0.226 \pm 0.003$ & $0.416 \pm 0.002$ & $0.279 \pm 0.001$ & $0.559 \pm 0.002$ \\
\hline Leu & ND & $0.074 \pm 0.003$ & $0.096 \pm 0.003$ & $0.390 \pm 0.001$ & $0.152 \pm 0.001$ & $0.415 \pm 0.005$ & $0.276 \pm 0.009$ & $0.549 \pm 0.002$ \\
\hline Ile & ND & ND & ND & $0.225 \pm 0.018$ & $0.101 \pm 0.003$ & $0.229 \pm 0.014$ & $0.178 \pm 0.009$ & $0.341 \pm 0.002$ \\
\hline Thr & $0.487 \pm 0.010$ & $0.465 \pm 0.007$ & $0.495 \pm 0.013$ & $0.391 \pm 0.018$ & $0.491 \pm 0.010$ & $0.398 \pm 0.007$ & $0.466 \pm 0.018$ & $0.391 \pm 0.012$ \\
\hline Pro & $0.084 \pm 0.008$ & $0.089 \pm 0.001$ & $0.136 \pm 0.007$ & $0.312 \pm 0.002$ & $0.188 \pm 0.007$ & $0.345 \pm 0.004$ & $0.296 \pm 0.006$ & $0.476 \pm 0.002$ \\
\hline Asp & $0.313 \pm 0.012$ & $0.264 \pm 0.008$ & $0.298 \pm 0.005$ & $0.538 \pm 0.003$ & $0.278 \pm 0.010$ & $0.535 \pm 0.009$ & $0.352 \pm 0.008$ & $0.692 \pm 0.006$ \\
\hline Met & $0.213 \pm 0.006$ & $0.219 \pm 0.003$ & $0.228 \pm 0.007$ & $0.305 \pm 0.001$ & $0.250 \pm 0.006$ & $0.297 \pm 0.004$ & $0.290 \pm 0.005$ & $0.329 \pm 0.006$ \\
\hline Glu & ND & $0.133 \pm 0.003$ & $0.178 \pm 0.017$ & $0.581 \pm 0.008$ & $0.245 \pm 0.016$ & $0.601 \pm 0.016$ & $0.435 \pm 0.005$ & $0.761 \pm 0.012$ \\
\hline Phe & ND & ND & ND & ND & ND & ND & ND & $0.042 \pm 0.002$ \\
\hline Lys & ND & ND & $0.091 \pm 0.009$ & $0.252 \pm 0.013$ & $0.080 \pm 0.006$ & $0.307 \pm 0.025$ & ND & $0.393 \pm 0.010$ \\
\hline His & $0.108 \pm 0.014$ & ND & $0.102 \pm 0.020$ & ND & $0.078 \pm 0.003$ & $0.140 \pm 0.014$ & $0.103 \pm 0.017$ & $0.183 \pm 0.011$ \\
\hline Tyr & $0.190 \pm 0.020$ & $0.205 \pm 0.003$ & $0.325 \pm 0.018$ & $0.326 \pm 0.004$ & $0.264 \pm 0.018$ & $0.328 \pm 0.009$ & $0.273 \pm 0.007$ & $0.321 \pm 0.009$ \\
\hline Cys & $0.180 \pm 0.005$ & $0.217 \pm 0.006$ & $0.332 \pm 0.012$ & $0.266 \pm 0.015$ & $0.286 \pm 0.003$ & $0.265 \pm 0.009$ & $0.185 \pm 0.007$ & $0.269 \pm 0.006$ \\
\hline Gln & $1.474 \pm 0.008$ & $1.318 \pm 0.012$ & $1.338 \pm 0.014$ & $1.237 \pm 0.006$ & $1.255 \pm 0.012$ & $1.256 \pm 0.006$ & $1.217 \pm 0.009$ & $1.320 \pm 0.008$ \\
\hline Hyp & $0.473 \pm 0.010$ & $0.432 \pm 0.003$ & $0.377 \pm 0.018$ & $0.546 \pm 0.006$ & $0.351 \pm 0.033$ & $0.313 \pm 0.002$ & $0.311 \pm 0.007$ & $0.533 \pm 0.007$ \\
\hline GABA(Ser) & $0.456 \pm 0.041$ & $0.453 \pm 0.030$ & $0.439 \pm 0.027$ & $1.273 \pm 0.022$ & $0.856 \pm 0.007$ & $1.501 \pm 0.018$ & $1.426 \pm 0.028$ & $1.734 \pm 0.042$ \\
\hline
\end{tabular}

Values are averages of three experiments \pm standard deviations. Tryptophan, hydroxylysine and cystine were not detected in all samples tested. The GC-FID analysis in this study could not distinguish GABA and Ser., because these two compounds showed an identical retention time. The values for GABA(Ser) were determined using a standard curve of GABA. ND, not detected.

obtained by GC-FID was, thus, considered to be GABA. The value of GABA (Ser) was determined using a standard curve constructed using GABA. To evaluate the effect of HP treatment on the amino acid distribution, the concentration of each amino acid in HP-treated and untreated samples were shown in a scatter plot (Fig. 1b). Most amino acids were distributed around a line with a slope of 0.9. This result indicated that the HP treatment showed no apparent effect on the free amino acid distribution in brown rice grains, which had been soaked in water, just after HP treatment.

\subsection{Free amino acid distribution dynamics in water-soaked brown rice during preservation}

HP-treated brown rice sample was preserved at $25^{\circ} \mathrm{C}$ for $4 \mathrm{~d}$ after HP treatment. The untreated control without HP treatment was also applied for preservation. Using amino acids concentration in samples preserved for 1 to 4 days, the scatter plots were made (Figure 2). The plots of amino acids distributed in a line with a slope between 1.2 and 1.4, being higher than 1.0. This result suggested that HP treatment improved the proteolysis and that the amino acids of high concentrations were released from degraded proteins. Among the free amino acid detected,
Ala, Gly, Val, Leu, Ile, Pro, Asp, Glu, Phe, Lys and His in HP-treated samples showed higher concentrations than those in untreated controls. For the typical examples of this group, time course of Ala, Gly and Glu concentration during preservation were shown in Fig. 3a. These 11 amino acids are relatively rich in the total amino acids in brown rice, including those in proteins [32]. In contrast, Thr, Met, Tyr, Cys and Gln in HP-treated and untreated samples did not show apparent differences in concentrations throughout the preservation period. For typical examples of this group, time course of Thr, Cys and Gln concentrations during preservation were shown in Fig. 3b. Thr, Met, Tyr and Cys were relatively poor in the total amino acids in brown rice grains. The possible explanation for these results is that HP treatment could modify proteolysis and/or amino acid metabolism in rice grains. As a result, HP treatment might cause the alteration of distribution of free amino acids in brown rice during preservation.

Two non-protein amino acids, GABA and Hyp, showed different responses during preservation (Fig. 3c). GABA showed increased concentration in HP-treated samples, whereas Hyp did not apparently increase by HP treatment. GABA is primarily produced from Glu and Pro by 

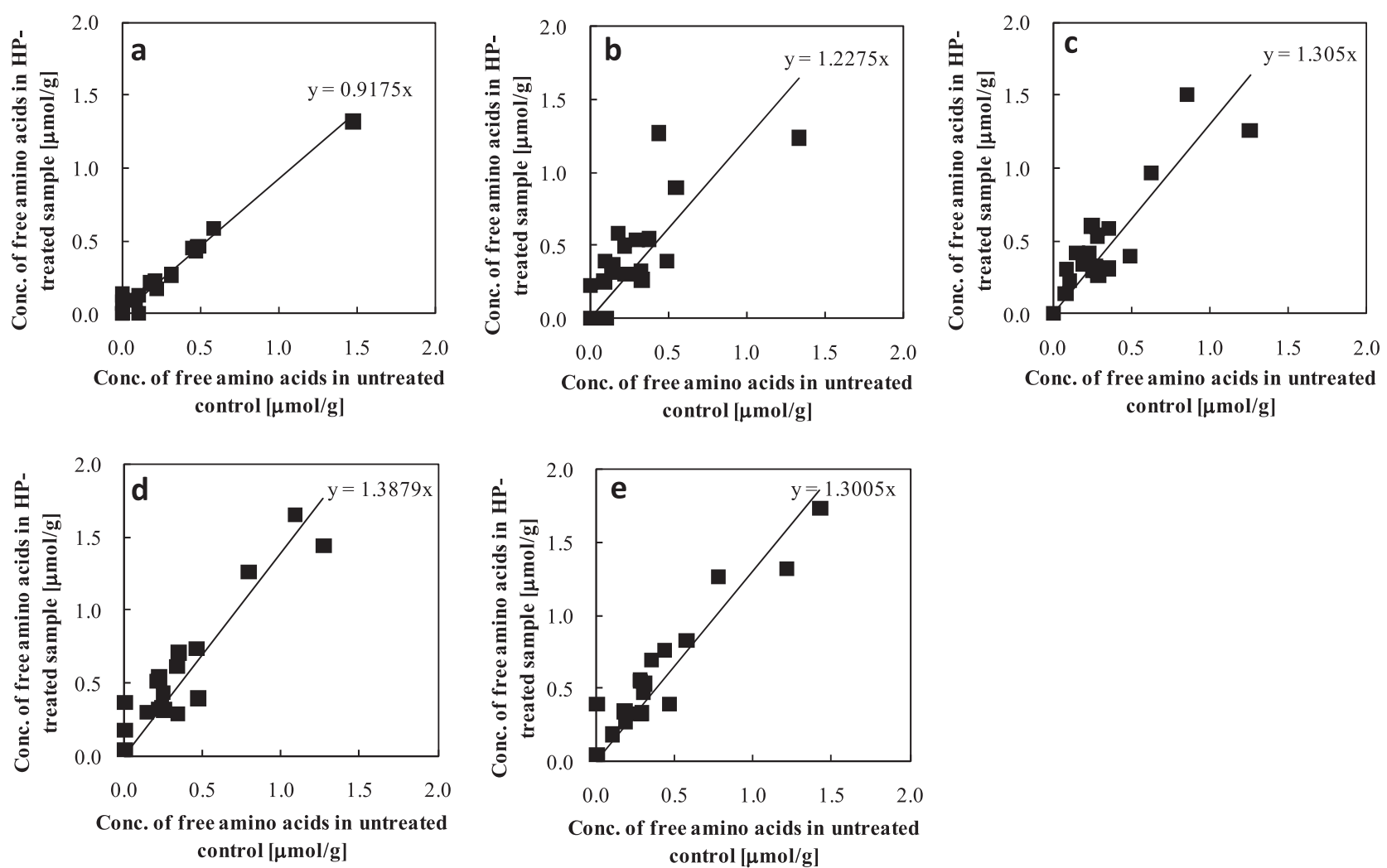

Fig. 2 Scatter plots of free amino acids concentration between HP-treated and untreated water-soaked samples during preservation for $0 \mathrm{~d}(\mathrm{a}), 1 \mathrm{~d}(\mathrm{~b}), 2 \mathrm{~d}(\mathrm{c}), 3 \mathrm{~d}(\mathrm{~d})$ and $4 \mathrm{~d}(\mathrm{e})$.
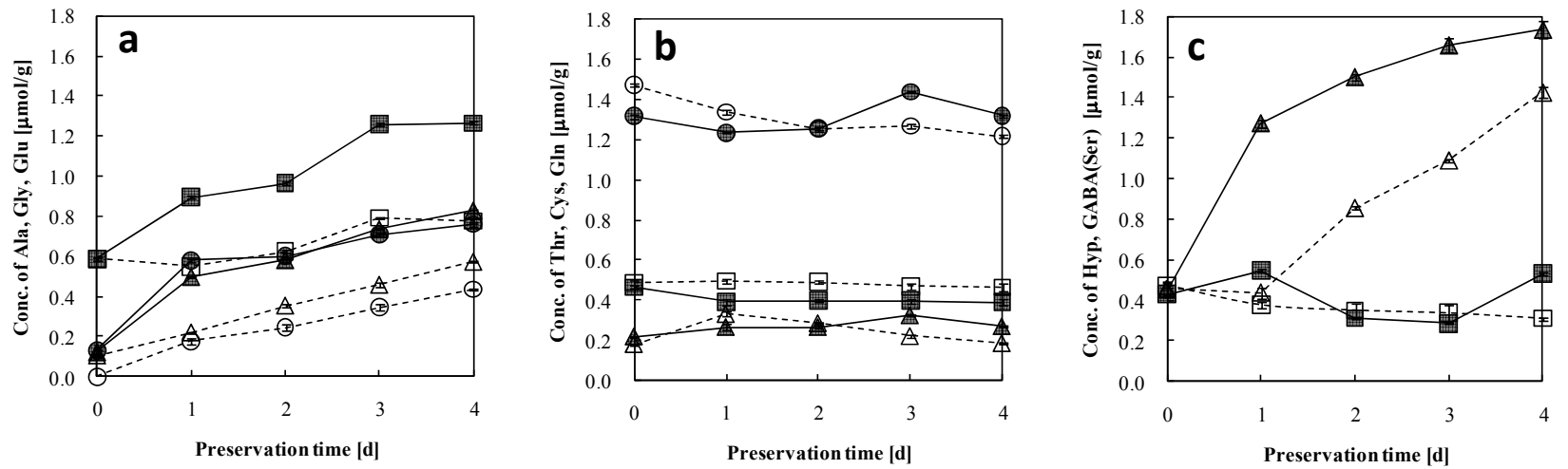

Fig. 3 Time course of certain amino acids concentration in HP-treated and untreated water-soaked samples during preservation. Ala (boxes), Gly (triangles) and Glu (circles) (a), Thr (boxes), Cys (triangles) and Gln (circles) (b) and GABA (triangles) and Hyp (boxes) (c) of HP-treated (closed symbols) and untreated samples (open symbols) were shown with error bars representing the standard deviations.

GAD. Saikusa et al. analyzed the distribution of free amino acids in rice grain during water soaking and showed increase in the contents of GABA during water soaking [1]. They suggested the possible contribution of $\mathrm{GAD}$ for the increase of GABA during water soaking. The increase of GABA in untreated control during preservation in our study was coincident with the result by Saikusa et al. In contrast, Hyp is primarily produced from Pro by prolyl 4-hydroxylase. The Pro concentration in the total amino acids in brown rice is lower than that of Glu. The Pro supply by HP-promoted proteolysis could be limited. Another possibility for the different dynamics of the two amino acids is the enzyme stability against HP treatment. In general, pressures of 200 to $300 \mathrm{MPa}$ are known to dissociate oligomeric proteins into their monomers, whereas monomeric proteins become denatured above $400 \mathrm{MPa}$ [33]. The HP effect on the structures and function of the two enzymes, GAD [34,35] and prolyl 
4-hydroxylase [36] with their isoforms, may be different. These assumptions could explain the different response to the HP treatment between GABA and Hyp.

In our previous paper, we reported that water-soaked soybean showed high accumulation of free amino acids and GABA by HP treatment and pointed out the contribution of both proteolysis and Glu metabolism [28]. The enhanced increase of GABA by HP treatment, in brown rice, thus, led us to construct following two hypothesis: (i) Glu supply was enhanced by the improved proteolysis by HP-treatment and (ii) the apparent activity of GAD was improved by HP-treatment.

\subsection{Effect of HP treatment on distribution of free} amino acids in Glu solution-soaked brown rice

As described above, the GABA concentration in the water-soaked brown rice was significantly increased during preservation after HP treatment, compared with untreated control. GABA would be produced via enzymatic reactions from Glu by GADs. This improvement of GABA increase in HP treated sample suggests that Glu supply was enhanced by the improved proteolysis by HP treatment and/or that the apparent activity of GADs was improved by HP treatment. Therefore, the soaking solution with Glu concentration of 0.01 to $0.5 \mathrm{~g} / \mathrm{ml}$ was used before HP treatment at $200 \mathrm{MPa}$ for $10 \mathrm{~min}$. The free amino acid concentration in the brown rice sample just after HP treatment was measured (Table 2). The brown rice samples, soaked in each soaking solution, without HP treatment were used as HP-untreated controls. Fig. 4 shows the scatter plots of each amino acid in HP-treated and HP-untreated samples. The plots of amino acids distributed around a line with a slope between 0.7 and 1.2, roughly being 1.0. The Glu concentration in the soaking solution showed no apparent effect on the slope (Fig. 4a to $4 \mathrm{~g}$ ). The increase of Glu concentration in the soaking solution caused to increase of Glu in the brown rice samples up to approximately $120 \mu \mathrm{mol} / \mathrm{g}$. The plots of Glu also distributed around a line with a slope of 1.0 (Fig. $4 \mathrm{~h}$ ). These results indicated that the HP treatment showed no apparent effect on the free amino acid distribution containing Glu in the brown rice samples, which had been soaked in 0 to $0.5 \mathrm{~g} / \mathrm{ml}$ Glu solution, just after HP treatment. GABA concentration in the brown rice samples increased with the increase of the Glu concentration in the soaking solution with 0 to $0.05 \mathrm{~g} / \mathrm{ml}$. In contrast, no obvious increase in GABA concentration was observed with the increase of the Glu concentration in the soaking solution with 0.05 to $0.1 \mathrm{~g} / \mathrm{ml}$. The GABA concentration decreased with the increase of the Glu concentration in the soaking solution with 0.1 to $0.5 \mathrm{~g}$ / $\mathrm{ml}$. These results suggested that Glu supplied into the brown rice samples was converted to GABA during soaking period, but the conversion could be inhibited with the high concentration of Glu in the soaking solution especially over $0.1 \mathrm{~g} / \mathrm{ml}$. No apparent effect of HP treatment on this conversion was observed in the brown rice samples just after HP treatment (0 d samples). Additionally, the Gln concentration of $0 \mathrm{~d}$ samples showed no obvious effect by the Glu concentration in the soaking solution. This result suggested that the conversion of Glu to Gln did not occur during soaking period.

\subsection{GABA concentration in Glu solution- soaked brown rice during preservation}

GABA, Glu, and Gln concentrations in the HP-treated and HP-untreated brown rice samples, which had been soaked in 0.01 to $0.5 \mathrm{~g} / \mathrm{ml}$ Glu solution, were analyzed during preservation at $25^{\circ} \mathrm{C}$ for $4 \mathrm{~d}$ after $\mathrm{HP}$ treatment (Fig. 5). In each concentration of the soaking solution, Gln concentration showed no apparent change in concentration during preservation in $\mathrm{HP}$-treated and HP-untreated samples. The concentration of Glu in the $\mathrm{HP}$-treated and $\mathrm{HP}-$ untreated samples at $0 \mathrm{~d}$ was increased with the concentration in soaking solution, however this amino acid showed a tendency to decrease in concentration during preservation. GABA showed increase in concentration during preservation in HP-treated and HP-untreated samples. These results indicated that, like the brown rice samples soaked in water, the conversion from Glu to GABA possibly via GADs occurred in the brown rice sample soaked in Glu solution during preservation. In HP-treated and HP-untreated samples, the GABA concentrations during preservation showed a tendency to increase with the increase in the Glu concentrations in the soaking solutions between 0 and $0.03 \mathrm{~g} / \mathrm{ml}$ (Fig. $5 \mathrm{a}$ to $5 \mathrm{c}$ ). Between 0.05 and $0.1 \mathrm{~g} / \mathrm{ml}$ of Glu in the soaking solution, no apparent effect on GABA concentration by increase in Glu concentration in the soaking solution was observed (Fig. 5d to 5f). These results suggested that Glu supplied into the brown rice samples during soaking were converted to GABA during preservation in the HP-treated and HP-untreated samples. In the samples soaked in 0.5 $\mathrm{g} / \mathrm{ml}$ Glu solution, however, GABA concentration during preservation showed an inhibition response, which was roughly lower than those soaked in $0.01 \mathrm{~g} / \mathrm{ml} \mathrm{Glu}$ solution (Fig. 5g). 
Table 2 Free amino acid concentration of HP-treated and HP-untreated Glu-soaked brown rice grains just after HP treatment ( $0 \mathrm{~d})$.

[unit: $\mu \mathrm{mol} / \mathrm{g}$-rice]

\begin{tabular}{|c|c|c|c|c|c|c|}
\hline & \multicolumn{2}{|c|}{$0.01 \mathrm{~g} / \mathrm{ml} \mathrm{Glu}$} & \multicolumn{2}{|c|}{$0.03 \mathrm{~g} / \mathrm{ml} \mathrm{Glu}$} & \multicolumn{2}{|c|}{$0.05 \mathrm{~g} / \mathrm{ml} \mathrm{Glu}$} \\
\hline & HP-untreated & HP-treated & HP-untreated & HP-treated & HP-untreated & HP-treated \\
\hline $\mathrm{Ala}$ & $0.611 \pm 0.007$ & $0.800 \pm 0.043$ & $0.667 \pm 0.003$ & $0.696 \pm 0.010$ & $0.834 \pm 0.038$ & $0.790 \pm 0.013$ \\
\hline Gly & $0.095 \pm 0.002$ & ND & $0.129 \pm 0.010$ & $0.153 \pm 0.069$ & $0.104 \pm 0.007$ & $0.104 \pm 0.007$ \\
\hline Val & $0.109 \pm 0.004$ & ND & $0.094 \pm 0.007$ & $0.169 \pm 0.006$ & $0.135 \pm 0.002$ & $0.130 \pm 0.006$ \\
\hline Leu & ND & ND & $0.066 \pm 0.004$ & $0.083 \pm 0.007$ & $0.069 \pm 0.001$ & $0.056 \pm 0.004$ \\
\hline Ile & ND & ND & $0.091 \pm 0.000$ & ND & $0.061 \pm 0.001$ & ND \\
\hline Thr & $0.353 \pm 0.000$ & $0.258 \pm 0.000$ & $0.711 \pm 0.037$ & $0.712 \pm 0.019$ & $1.126 \pm 0.014$ & $0.533 \pm 0.027$ \\
\hline Pro & $0.089 \pm 0.000$ & ND & $0.102 \pm 0.009$ & $0.105 \pm 0.002$ & $0.103 \pm 0.006$ & $0.084 \pm 0.002$ \\
\hline Asp & $0.617 \pm 0.007$ & $0.205 \pm 0.012$ & $0.349 \pm 0.012$ & $0.387 \pm 0.012$ & $0.477 \pm 0.002$ & $0.317 \pm 0.006$ \\
\hline Met & $0.198 \pm 0.002$ & $0.143 \pm 0.017$ & $0.263 \pm 0.004$ & $0.263 \pm 0.008$ & $0.214 \pm 0.006$ & $0.207 \pm 0.003$ \\
\hline Glu & $3.213 \pm 0.089$ & $2.473 \pm 0.241$ & $16.378 \pm 0.187$ & $15.982 \pm 0.354$ & $34.771 \pm 0.655$ & $22.746 \pm 0.916$ \\
\hline Phe & ND & ND & ND & ND & ND & ND \\
\hline Lys & ND & ND & ND & ND & $0.150 \pm 0.017$ & ND \\
\hline His & ND & ND & ND & ND & ND & ND \\
\hline Tyr & $0.099 \pm 0.013$ & $0.095 \pm 0.003$ & $0.244 \pm 0.015$ & $0.182 \pm 0.010$ & $0.252 \pm 0.029$ & $0.189 \pm 0.023$ \\
\hline Cys & ND & ND & ND & ND & ND & ND \\
\hline Gln & $1.342 \pm 0.011$ & $1.583 \pm 0.049$ & $1.631 \pm 0.011$ & $1.475 \pm 0.035$ & $1.760 \pm 0.061$ & $1.543 \pm 0.018$ \\
\hline Hyp & $0.379 \pm 0.017$ & $0.591 \pm 0.017$ & $0.251 \pm 0.021$ & $0.332 \pm 0.013$ & $0.837 \pm 0.013$ & $0.330 \pm 0.012$ \\
\hline \multirow[t]{3}{*}{ GABA(Ser) } & $1.112 \pm 0.057$ & $1.649 \pm 0.045$ & $2.052 \pm 0.098$ & $2.043 \pm 0.021$ & $2.344 \pm 0.015$ & $1.876 \pm 0.050$ \\
\hline & \multicolumn{2}{|c|}{$0.08 \mathrm{~g} / \mathrm{ml} \mathrm{Glu}$} & \multicolumn{2}{|c|}{$0.1 \mathrm{~g} / \mathrm{ml} \mathrm{Glu}$} & \multicolumn{2}{|c|}{$0.5 \mathrm{~g} / \mathrm{ml} \mathrm{Glu}$} \\
\hline & HP-untreated & HP-treated & HP-untreated & HP-treated & HP-untreated & HP-treated \\
\hline Ala & $0.701 \pm 0.003$ & $0.653 \pm 0.008$ & $0.696 \pm 0.007$ & $0.865 \pm 0.010$ & $1.020 \pm 0.003$ & $0.850 \pm 0.020$ \\
\hline Gly & $0.096 \pm 0.005$ & $0.110 \pm 0.013$ & $0.106 \pm 0.007$ & $0.097 \pm 0.005$ & $0.083 \pm 0.003$ & $0.096 \pm 0.015$ \\
\hline Val & $0.076 \pm 0.002$ & $0.057 \pm 0.000$ & $0.081 \pm 0.006$ & $0.171 \pm 0.008$ & $0.227 \pm 0.002$ & $0.088 \pm 0.006$ \\
\hline Leu & ND & $0.051 \pm 0.003$ & $0.056 \pm 0.003$ & $0.066 \pm 0.012$ & $0.071 \pm 0.012$ & $0.067 \pm 0.005$ \\
\hline Ile & ND & ND & $0.062 \pm 0.000$ & ND & $0.088 \pm 0.007$ & $0.112 \pm 0.070$ \\
\hline Thr & $0.179 \pm 0.002$ & $0.112 \pm 0.018$ & $0.556 \pm 0.008$ & $0.565 \pm 0.007$ & ND & ND \\
\hline Pro & ND & ND & $0.090 \pm 0.005$ & $0.084 \pm 0.008$ & ND & ND \\
\hline Asp & $0.443 \pm 0.004$ & $0.432 \pm 0.008$ & $0.392 \pm 0.008$ & $0.417 \pm 0.002$ & $0.887 \pm 0.014$ & $0.557 \pm 0.026$ \\
\hline Met & $0.175 \pm 0.010$ & $0.156 \pm 0.009$ & $0.214 \pm 0.008$ & $0.217 \pm 0.018$ & ND & ND \\
\hline Glu & $45.993 \pm 0.650$ & $37.362 \pm 0.804$ & $53.763 \pm 0.368$ & $50.878 \pm 0.785$ & $118.093 \pm 0.781$ & $94.599 \pm 2.835$ \\
\hline Phe & ND & ND & ND & ND & ND & ND \\
\hline Lys & ND & ND & ND & ND & ND & ND \\
\hline His & ND & ND & ND & ND & ND & ND \\
\hline Tyr & $0.164 \pm 0.019$ & $0.064 \pm 0.016$ & $0.321 \pm 0.024$ & $0.236 \pm 0.043$ & $0.107 \pm 0.018$ & $0.162 \pm 0.012$ \\
\hline Cys & ND & ND & ND & ND & ND & ND \\
\hline Gln & $1.676 \pm 0.092$ & $1.707 \pm 0.064$ & $2.170 \pm 0.030$ & $1.848 \pm 0.126$ & $2.040 \pm 0.150$ & $1.631 \pm 0.062$ \\
\hline Нyp & $0.297 \pm 0.065$ & $0.242 \pm 0.024$ & $0.233 \pm 0.021$ & $0.346 \pm 0.019$ & $0.243 \pm 0.037$ & $0.240 \pm 0.020$ \\
\hline GABA(Ser) & $2.049 \pm 0.036$ & $2.068 \pm 0.009$ & $1.746 \pm 0.018$ & $2.308 \pm 0.045$ & $1.161 \pm 0.033$ & $1.173 \pm 0.008$ \\
\hline
\end{tabular}

Values are averages of three experiments \pm standard deviations. Tryptophan, hydroxylysine and cystine were not detected in all samples tested. ND, not detected.

The HP-treated samples, which had been soaked in 0.01 to $0.1 \mathrm{~g} / \mathrm{ml}$ Glu solution, showed significantly higher GABA concentrations through the preservation period than those without HP treatment. This result was coincident with that obtained using the water-soaked samples. Thus, the conversion from Glu to GABA could be promoted by the HP treatment. The increased concentrations of GABA in the HP-treated samples were remarkable at the $1 \mathrm{~d}$ and $2 \mathrm{~d}$ preservation as shown in Fig. 5 a to 5f. This observation suggested that HP treatment enhanced the initial production rate of GABA. The HP treatment would possibly improve the apparent activity of GADs during the preservation from $0 \mathrm{~d}$ to $2 \mathrm{~d}$. The samples soaked in $0.5 \mathrm{~g} / \mathrm{ml}$ Glu solution showed no apparent effect on GABA concentrations by HP treatment. The Glu concentration of HP-treated and HP-untreated samples at $0 \mathrm{~d}$ were approximately 95 and $120 \mu \mathrm{mol} / \mathrm{g}$, respectively, indicating that the initial substrate supply for GADs was not limited. The apparent activity of GADs might be inhibited by the Glu with the high concentra- 


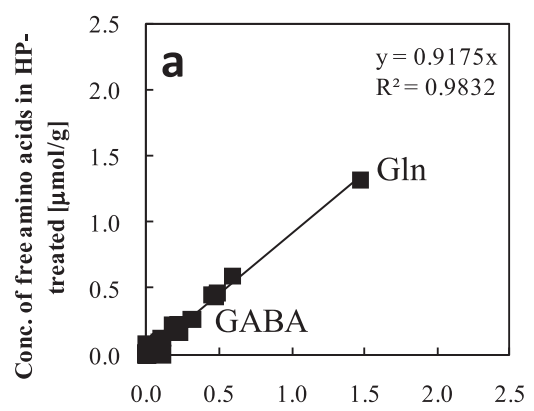

Conc. of free amino acids in HP-untreated (Glu 0) $[\mu \mathrm{mol} / \mathrm{g}]$

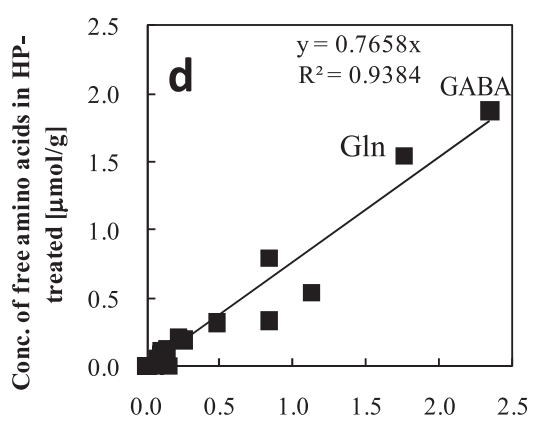

Conc. of free amino acids in HP-untreated (Glu 0.05) $[\mu \mathrm{mol} / \mathrm{g}]$

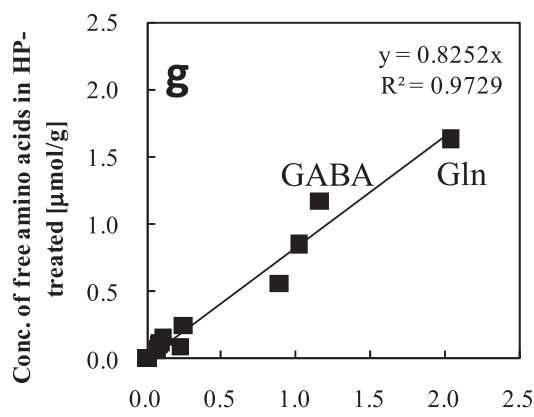

Conc. of free amino acids in HP-untreated (Glu 0.50) $[\mu \mathrm{mol} / \mathrm{g}]$

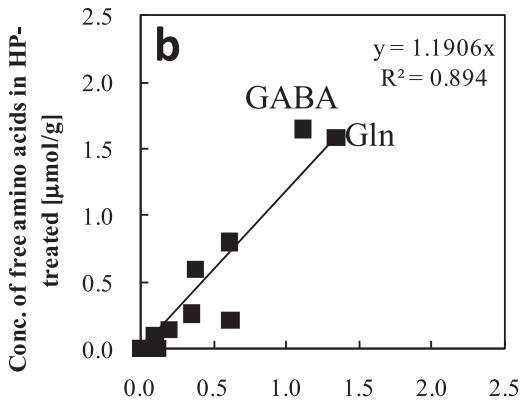

Conc. of free amino acids in HP-untreated (Glu 0.01) $[\mu \mathrm{mol} / \mathrm{g}]$

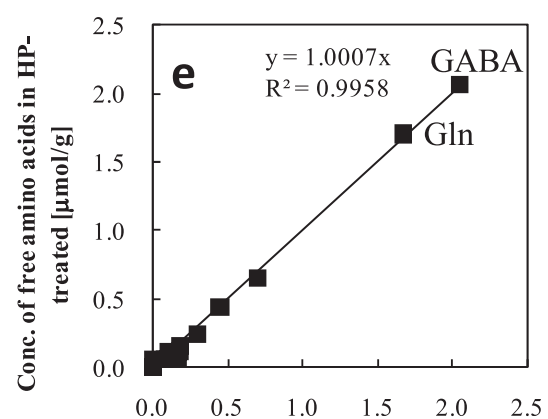

Conc. of free amino acids in HP-untreated (Glu 0.08) $[\mu \mathrm{mol} / \mathrm{g}]$

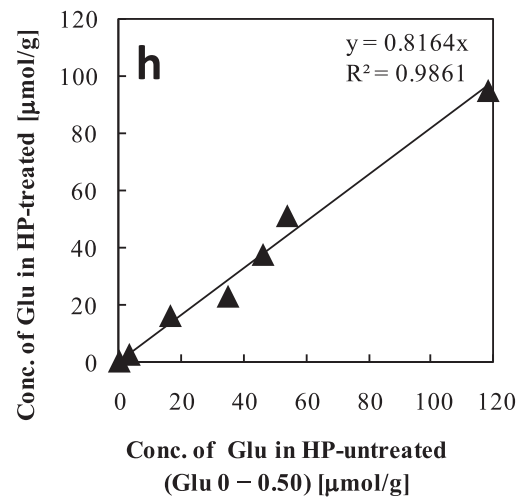

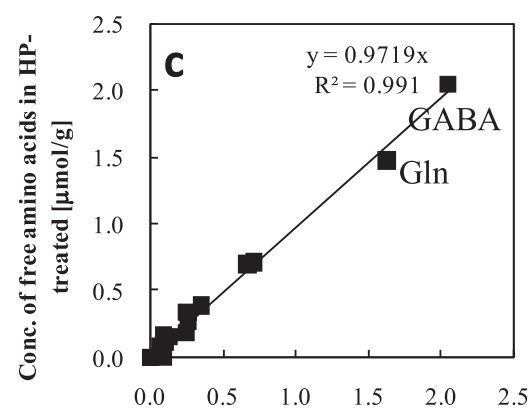

Conc. of free amino acids in HP-untreated (Glu 0.03) $[\mu \mathrm{mol} / \mathrm{g}]$

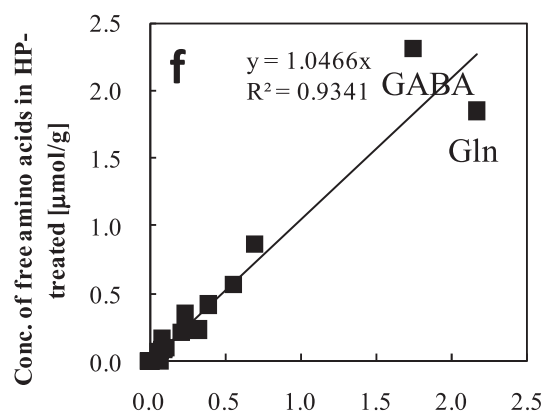

Conc. of free amino acids in HP-untreated (Glu 0.10) $[\mu \mathrm{mol} / \mathrm{g}]$

Fig. 4 Scatter plots of free amino acids concentration between HP-treated and HP-untreated samples which had been soaked in Glu concentration of 0 (a), 0.01 (b), 0.03 (c), 0.05 (d), 0.08 (e), 0.10 (f) and $0.50 \mathrm{~g} / \mathrm{ml}$ (g) just after HP treatment (0 d). Glu concentrations in HP-treated and HP-untreated samples soaked in 0 to $0.5 \mathrm{~g} / \mathrm{ml} \mathrm{Glu}$ solution was shown (h).

tion.

The relationship between initial Glu concentration and initial GABA production rate of the HP-treated and HP-untreated samples were analyzed using the GABA concentrations at $0 \mathrm{~d}$ to $2 \mathrm{~d}$ preservation (Fig. 6). In the brown rice samples without HP treatment, the increase of Glu concentration at $0 \mathrm{~d}$ increased the initial GABA production rate below approximately $16 \mu \mathrm{mol} / \mathrm{g}$ Glu concentrations. The initial GABA production rate of the samples without HP treatment was not affected by the Glu concentrations over $16 \mu \mathrm{mol} / \mathrm{g}$ Glu concentration. The kinetic parameters of purified GADs from rice were analyzed based on the liner Lineweaver-Burk plot, suggest- ing these followed the Michaelis-Menten kinetics [34, 35]. The relationship between initial Glu concentration and initial GABA production rate described above suggested that the GADs in the rice grains also followed Michaelis-Menten kinetics as reported for purified GADs.

In the initial Glu concentration between 0 and $23 \mu \mathrm{mol} / \mathrm{g}$, the initial GABA production rate of the $\mathrm{HP}$-treated sample showed increase with the increase of the initial Glu concentration. This increase was higher in HP-treated samples than in the untreated samples. The accelerated initial GABA production rate by HP treatment strongly supports the hypothesis that the apparent 

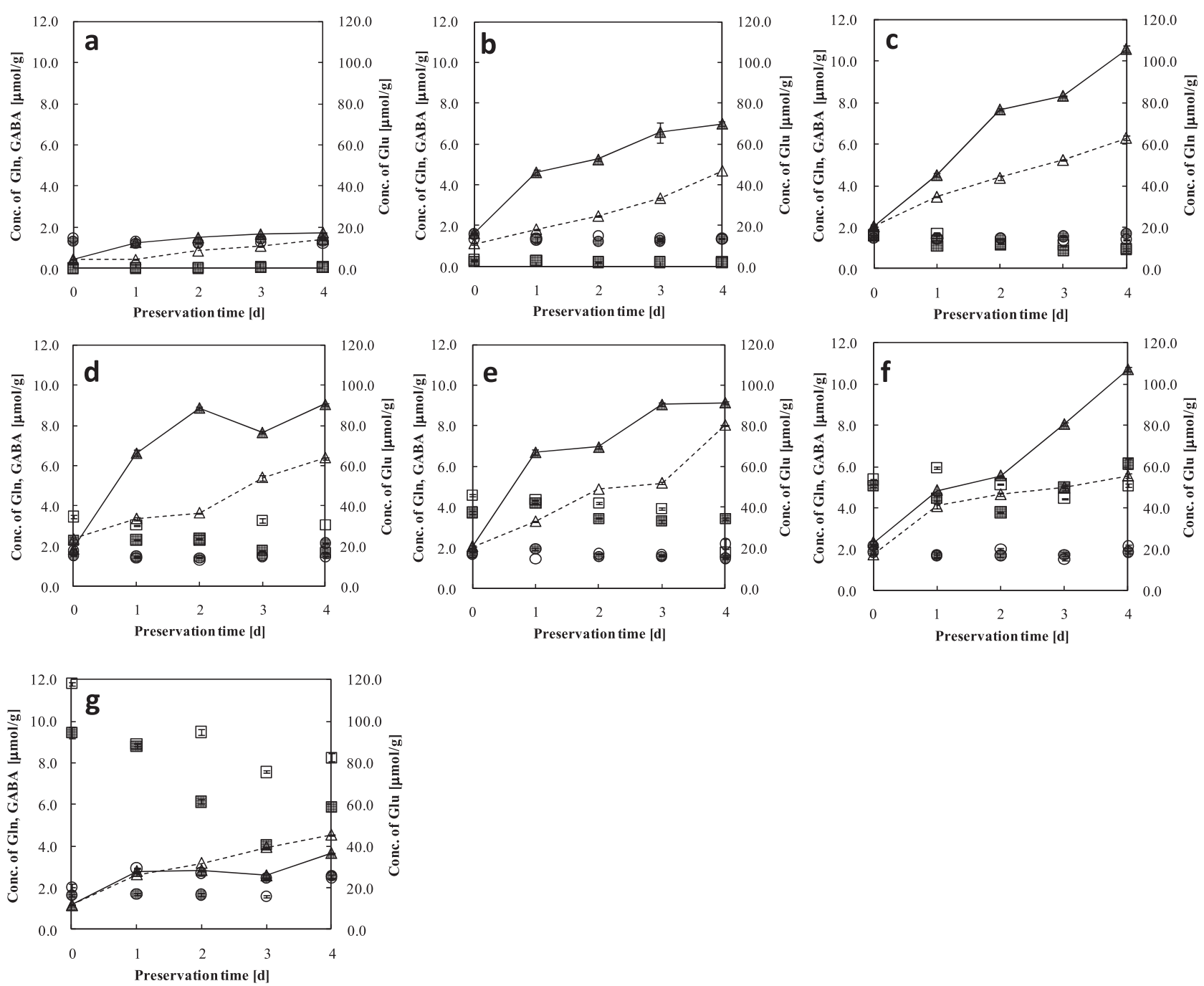

Fig. 5 Time course of GABA (triangles), Glu (boxes), and Gln (circles) concentrations in HP-treated (closed symbols) and HP-untreated (open symbols) samples, which had been soaked in Glu concentration of 0 (a), 0.01 (b), 0.03 (c), 0.05 (d), 0.08 (e), 0.10 (f) and $0.50 \mathrm{~g} / \mathrm{ml}(\mathrm{g})$ during preservation. Symbols were shown with error bars representing the standard deviations.

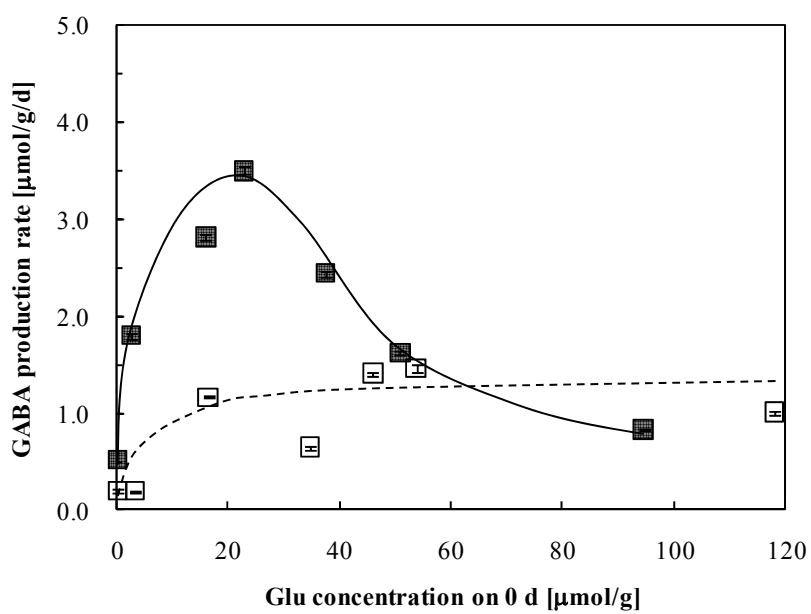

Fig. 6 Correlation between initial Glu concentration and GABA production rate in HP-treated (closed boxes) and HP-untreated (open boxes) samples. Symbols were shown with error bars representing the standard deviations. activity of GADs was improved by HP-treatment. In brown rice, GAD activity was highly localized in embryo [37]. The HP treatment could damage the membrane structures in the brown rice, resulting in the improvement of mass transfer within the grains. The association efficiency between GADs and Glu could, thus, be improved in the HP-treated samples. This assumption could well explain the acceleration of initial GABA production rate by HP treatment. The improvement of apparent GAD activity and proteolysis by HP treatment could significantly accelerate the initial GABA production rate. Interestingly, in the initial Glu concentration between 23 and $95 \mu \mathrm{mol} / \mathrm{g}$, the initial GABA production rate of the HP-treated sample decreased with the increase of the initial Glu concentration. This result suggested a substrate inhibition effect was occurred in the HP-treated samples at the high initial Glu concentration. To our 
knowledge, there have been no reports showing substrate inhibition effect of GADs. For the better understanding of the inhibition effect for GABA production rate in HP-treated samples soaked in high concentration Glu solution still needs further investigation.

\section{Conclusion}

In this study, we supplied Glu into brown rice grains and allowed an enzymatic conversion from Glu to GABA induced by HP treatment. The brown rice grains acted as a bioreactor with a metabolic function for proteolysis and Glu conversion to GABA. The production level of GABA was affected by the initial Glu concentration, which could be controlled by the Glu concentration in the soaking solution. Moreover, the initial GABA production rate was accelerated by HP treatment at $200 \mathrm{MPa}$ for $10 \mathrm{~min}$. These results provide feasibility for a novel use of HP technology to alter the metabolic pathways in a cellular biological material and to accumulate useful metabolites, leading to an insight into a new technology for functional foods processing.

\section{Acknowledgement}

This work was financially supported by the program Niigata Prefecture Collaboration of Regional Entities for the Advancement of Technological Excellence of the Japan Science and Technology Agency and by the Iijima Memorial Foundation for the Promotion of Food Science and Technology.

\section{References}

1) T. Saikusa, T. Horino, Y. Mori; Distribution of free amino acids in the rice kernel and kernel fractions and the effect of water sooaking on the distribution. J. Agric. Food. Chem., 42 1122-1125 (1994).

2) T. Saikusa, T. Horino, Y. Mori; Accumulation of $\gamma$-aminobutyric acid (Gaba) in the rice germ during water soaking. Biosci. Biotech. Biochem., 58, 2291-2292 (1994).

3) S. Ohtsubo, S. Asano, K. Sato, I. Matsumoto; Enzymatic production of $\gamma$-aminobutyric acid using rice (Oryza sativa) germ. Food Sci. Technol. Res., 6, 208-211 (2000).

4) Y. Ueno, K. Hayakawa, S. Takahashi, K. Oda; Purification and characterization of glutamate decarboxylase from Lactobacillus brevis. Biosci. Biotech. Biochem., 61, 1168-1171 (1997).

5) M. Nomura, H. Kimoto, Y. Someya, S. Furukawa, I. Suzuki;
Production of $\gamma$-aminobutyric acid by cheese starters during cheese ripening. J. Dairy Sci., 81, 1486-1491 (1998).

6) C. Jakobs, J. Jaeken, K. M. Gibsonm; Inherited disorders of GABA metabolism. J. Inherit. Metab. Dis., 16, 704-715 (1993).

7) C. G. Wong, T. Bottiglieri, O. C. Snead III; GABA, $\gamma$-hydroxybutyric acid, and neurological disease. Ann. Neurol., 54 (Suppl. 6), S3-S12 (2003).

8) J. P. P. M. Smelt; Recent advances in the microbiology of high pressure processing. Trends Food Sci. Technol., 9, 152-158 (1998).

9) K. Fujii, A. Ohtani, J. Watanabe, H. Ohgoshi, T. Fujii, K. Honma; High-pressure inactivation of Bacillus cereus spores in the presence of argon. Int. J. Food Microbiol., 72, 239-242 (2002).

10) C. E. O'Reilly, A. L. Kelly, P. M. Murphy, T. P. Beresford; High pressure treatment: applications in cheese manufacture and ripening. Trends Food Sci. Technol., 12, 51-59 (2001).

11) P. Montero, M. D. Fernandez-Diaz, M. C. Gomez-Guillen; Characterization of gelatin gels induced by high pressure. Food Hydrocoll., 16, 197-205 (2002).

12) B. Krebbers, A. M. Matser, M. Koets, R. W. Van den Berg; Quality and storage-stability of high-pressure preserved green beans. J. Food Eng., 54, 27-33 (2002).

13) S. Buzrul, H. Alpas, A. Largeteau, G. Demazeau; Inactivation of Escherichia coli and Listeria innocua in kiwifruit and pineapple juices by highhydrostatic pressure. Int. J. Food Microbiol., 124, 275-278 (2008).

14) S. Castro, J. Saraiva, J. Lopes-da-Silva, I. Delgadillo, A. Loey, C. Smout, M. Hendrickx; Effect of thermal blanching and of high pressure treatments on sweet green and red bell pepper fruits (Capsicum annuum L.). Food Chem., 107, 1436-1449 (2008).

15) M. Capellas, M. Mor-Mur, E. Sendra, R. Pla, B. Guamis; Populations of aerobic mesophils and inoculated E. coli during storage of fresh goat's milk cheese treated with high pressure. J. Food Protect., 59, 582-587 (1996).

16) B. Gudbjornsdottir, A. Jonsson, H. Hafsteinsson, V. Heinz; Effect of high-pressure processing on Listeria spp. and on the textural and microstructural properties of cold smoked salmon. LWT-Food Sci. Technol., 43, 366-374 (2010).

17) A. Sasagawa, J. Hoshino, A. Kobayashi, T. Nishiumi, A. Suzuki, T. Fujii, T. Konishi, A. Yamazaki, A. Yamada; Fermentation control of Kimchi by high-pressure treatment and characteristics (in Japanese). Rev. High Pressure Sci. Technol., 16, 167-178 (2006).

18) A. Sasagawa, A. Yamazaki, A. Kobayashi, J. Hoshino, T. Ohshima, M. Sato, T. Fujii, A. Yamada; Inactivation of Bacillus subtilis spores by a combination of hydrostatic high- 
pressure and pulsed electric field treatments. Rev. High Pressure Sci. Technol., 16, 45-53 (2006).

19) E. Y. Wuytack, C. W. Michiels; A study on the effects of high pressure and heat on Bacillus subtilis spores at low pH. Int. J. Food Microbiol., 64, 333-341 (2001).

20) Y. Aoyama, Y. Shigeta, T. Okazaki, Y. Hagura, K. Suzuki; Germination and inactivation of Bacillus subtilis spores under combined conditions of hydrostatic pressure and medium temperature. Food Sci. Technol. Res., 11, 101-105 (2005).

21) Y. Estrada-Giron, B. G. Swanson, G. V. Barbosa-Canovas; Advances in the use of high hydrostatic pressure for processing cereal grains and legumes. Trends Food Sci. Technol., 16, 194-203 (2005).

22) R. Hayashi; High pressure in bioscience and biotechnology: pure science encompassed in pursuit of value. Biochim. Biophys. Acta., 1595, 397-399 (2002).

23) D. Knorr, V. Heinz, R. Buckow; High pressure application for food biopolymers. Biochim. Biophys. Acta., 1764, 619-631 (2006).

24) M. N. Eshtiaghi, R. Stute, D. Knorr; High-pressure and freezing pretreatment effects on drying, rehydration, texture and color of green beans, carrots and potatoes. J. Food Sci., 59, 1168-1170 (1994).

25) S. Ueno, T. Izumi, T. Fujii; Estimation of damage to cells of Japanese radish induced by high pressure with drying rate as index. Biosci. Biotechnol. Biochem., 73, 1699-1703 (2009).

26) S. Ueno, T. Shigematsu, K. Kuga, M. Saito, M. Hayashi, T. Fujii,; High-pressure induced transformation of onion (in Japanese). Jpn. J. Food Eng., 10, 37-43 (2009).

27) W. Suthanthangjai, P. Kajda, I. Zabetakis; The effect of high hydrostatic pressure on the anthocyanins of raspberry (Rubus idaeus). Food Chem., 90, 193-197 (2005).

28) S. Ueno, T. Shigematsu, T. Watanabe, K. Nakajima, M. Murakami, M. Hayashi, T. Fujii; Generation of free amino acids and $\gamma$-aminobutyric acid in water-soaked soybean by high-hydrostatic pressure processing. J. Agric. Food Chem., 58, 1208-1213 (2010).

29) S. Ueno, M. Hayashi, T. Shigematsu, T. Fujii; Formation of green-blue compounds in Brassica rapa root by high pressure processing and subsequent storage. Biosci. Biotechnol. Biochem., 73, 943-945 (2009).

30) M. Kinefuchi, M. Sekiya, A. Yamazaki, K. Yamamoto; Accumulation of GABA in brown rice by high pressure treatment. (in Japanese). Nippon Shokuhin Kagaku Kougaku Kaishi, 46, 323-328 (1999).

31) M. Nozal, J. Bernal, M. Toribio, J. Diego, A. Ruiz; Rapid and sensitive method for determining free amino acids in honey by gas chromatography with flame ionization or mass spectrometric detection. J. Chromatgr. A, 1047, 137-146 (2004).

32) Y. Kagawa; Standard tables of food composition in Japan: fifth revised and enlarged ed. (in Japanese), Kagawa Nutrition University Publishing Division, Tokyo. (2005).

33) F. Meersman, K. Heremans; High hydrostatic pressure effects in the biosphere: from molecules to microbiology. In "High-pressure microbiology" C. Michiels, D. H. Barlett, A. Aertsen (eds.) pp. 1-17, ASM Press, Washington DC, USA (2008).

34) H. Zhang, H. -Y. Yao, F. Chen, X. Wang; Purification and characterization of glutamate decarboxylase from rice germ. Food Chem., 101, 1670-1676 (2007).

35) L. Wang, D. X. Xu, Y. G. Lv, H. Zhang; Purification and biochemical characterization of a novel glutamate decarboxylase from rice bran. J. Sci. Food Agric., 90, 1027-1033 (2010).

36) P. Tiainen, J. Myllyharju, P. Koivunen; Characterization of a second Arabidopsis thaliana prolyl 4-hydroxylase with distinct substrate specificity. J. Biol. Chem., 280, 1142-1148(2006).

37) L. L. Liu, H. Q. Zhai, J.-M. Wan; Accumulation of $\gamma$-aminobutyric acid in giant-embryo rice grain in relation to glutamate decarboxylase activity and its gene expression during water soaking. Cereal Chem., 82, 191-196 (2005). 


\title{
和文要約
}

\section{高圧処理による玄米のグルタミン酸から $\gamma$-アミノ酪酸への バイオコンバージョン}

\author{
重松 亨 $^{1, \dagger}$ ，村上美奈 ${ }^{1}$, 中島加奈子 ${ }^{1}$, 宇野義幸 ${ }^{1}$, 坂野新太 ${ }^{1}$, \\ 梄原優佳 ${ }^{1}$ ，林真由美 ${ }^{1}$ ，上野茂昭 ${ }^{2}$ ，藤井智幸 ${ }^{1,2}$ \\ 1 新潟薬科大学応用生命科学部 食品科学科, ${ }^{2}$ 東北大学大学院農学研究科
}

本研究では，玄米にグルタミン酸を供給し高圧処理 を施すことで, グルタミン酸から $\gamma$ アアミノ酪酸 (GABA) への変換反応への高圧処理の効果を検討した. 水浸漬 した玄米に $200 \mathrm{MPa} ， 10$ 分間の高圧処理を施し，その 後の保存中に打ける遊離アミノ酸組成の変動を解析し た. $25^{\circ} \mathrm{C} 4$ 日間の保存期間に高圧処理玄米中の GABA を含むいくつかのアミノ酸の濃度が経時的に増加し, 未処理試料に比べて高い值を示した，高圧処理を施し
た立米粒をバイオリアクタとして用い GABAを生産す る可能性を検討するために，玄米の浸漬水中にグルタ ミン酸を添加し高圧処理を施す実験を行った。その結 果, 浸漬液中のグルタミン酸濃度の増加に伴い, 保存 中の GABA 濃度が増加し, GABA 生成初速度は高圧処 理により加速された．これらの結果から，高圧処理に よりアミノ酸代謝が促進され，有用代謝産物を蓄積す る，新しい用途の可能性が示された。 